\title{
Inherited disorders of the skin in human and mouse: from development to differentiation
}

\author{
RYAN F.L. O'SHAUGHNESSY and ANGELA M. CHRISTIANO* \\ Departments of Dermatology and Genetics and Development, Columbia University, New York, USA
}

\begin{abstract}
The last ten years has revealed some of the key players in the development and differentiation of the hair follicle and the epidermis in general. In this review, we discuss how our current understanding of these processes has been made possible by the elucidation of the molecular basis of human inherited diseases and mouse mutants which display defects in the hair and epidermis. For examples, the study of ectodermal dysplasias and the basal cell carcinoma predisposition disease Gorlin syndrome have allowed the determination of signalling hierarchies critical in the formation of the hair follicle. Epidermolytic diseases and hyperkeratoses have focussed attention on the importance of the programs of keratin expression, while ichthyoses provide insight in the final stage of epidermal development, cornification. Finally, the increasing range of diseases and mouse models exhibiting alopecias are revealing the critical pathways in control of the hair follicle cycle.
\end{abstract}

KEY WORDS: hair follicle, epithelial-mesenchymal interaction, alopecia, keratin, cornified envelope

\section{An overview of epidermal development}

The epidermis is almost unique in that it continues to proliferate and differentiate throughout life. These processes are manifest in the formation of cornified squames and the continual cycling of hair follicles. There are many diseases that effect the development and differentiation of the epidermis and its adnexae, including the hair, teeth, nails and sweat glands. The discovery of the genetic basis of these diseases is the primary source of insight into the molecular mechanisms of epidermal development and differentiation. Also targeted and tissue specific disruption of genes in the mouse that lead to epidermal defects are providing valuable approaches in determining the genes responsible for as yet uncharacterized diseases.

The epidermis and its associated appendages, such as hair, claws and sweat glands, arise from the embryonic ectoderm. It should be noted that at the beginning of embryogenesis, the ectoderm gives rise to two distinct lineages. These are the ectoderm proper, which is the source of the epidermis, the corneal, nasal, vaginal and part of the oral epithelia, and the neuroderm, which gives rise to the cells of the central nervous system and neural crest cells. The latter develop into several types of cells including melanocytes. The appendages associated with the oral epithelia are the teeth, which in early development use the same gene cascade as that of hair formation (Pispa and Thesleff, 2003). The development of the mouse epidermis from the ectoderm starts at E9.5, concomitantly with dermis individualization, with the formation of a single layer of epidermal cells overlayed by the periderm, a protective simple epithelium. From E13.5 onwards, this single layer of keratinocytes develops into a stratified epithelium, with a complete barrier forming before birth from around E16.5-17, when the periderm sheds (Fig. 1). The presence of an epidermal barrier at this time point can be demonstrated by the ability of the embryos to exclude dye (Hardman et al., 1998). The tooth germs appear by E12 in the oral cavity, while the sweat buds form in the E16 foot pad epidermis. Concerning hair follicle morphogenesis, the first vibrissa (whisker) placodes appear at E12.5, whereas the hair pelage placodes form from E14.5 onwards. It should be noted that not only are vibrissa patterned earlier than pelage hair follicles, but that there are many other differences during morphogenesis and cycling. At birth, the whisker shafts are present, whereas the pelage hairs have not yet emerged from the hair follicles. The first pelage hair cycle proper starts around three weeks postnatally, with the first regression phase. The hair follicles then progress through cycles of growth (anagen), involution (catagen) and regression (telogen) which takes approximately 20 days throughout the life of the mouse and anywhere up to six years in humans. The epidermis is also constantly renewing itself every $10-12$ days in the mouse ( 28 days in the human), as there is a need to replace shed squames to maintain barrier function. There are human diseases that effect any or all of this processes, from the earliest point of differentiation of the ectoderm, through to terminal differentiation of the epidermis and hair follicle cycling (Fig. 1). In this review, we aim to

Abbreviations used in this paper: EDA, ectodysplasin; EDAR, ectodysplasin receptor; HED, hypohidrotic ectodermal dysplasia; shh, sonic hedgehog gene.

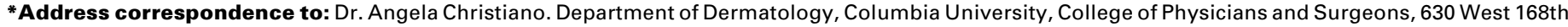
Street VC 15-204, New York, NY 10032, USA. Fax: +1-212-305-7391. e-mail: amc65@columbia.edu
} 
provide a broad overview of the field, providing examples of some of the diseases that affect skin differentiation and development and examining the potential molecular basis of these diseases. Wherever possible comparison with spontaneous mouse mutants or transgenic models that recapitulate the human disease will be made.

\section{Diseases of development: the ectodermal dysplasias}

The blueprint for hair follicles, sweat glands, claws and teeth is laid down during embryonic development. This process starts with the formation of thickenings of the epidermal layer, called placodes. These are brought about by reciprocal signaling between the epithelial cells and the underlying mesenchyme. The nature of these signals has been well studied during hair and tooth development in the mouse embryo. In humans, the inability to properly produce or pattern these placodes leads to diseases referred to as the ectodermal dysplasias. Classical ectodermal dysplasias present with the following generalized symptoms: lack or dysgenesis of the teeth, hair follicles, nails and sweat glands with in some cases associated neurological disorders. The recent discovery of the genes responsible for one of these diseases has shed light on the molecular basis of epidermal appendage development and has focused attention on one important signaling pathway in particular. Hypohidrotic ectodermal dysplasias (HED) are a class of diseases in which patients display abnormalities in the teeth, hair and sweat glands. There are two forms with identical symptoms, $\mathrm{X}$ linked

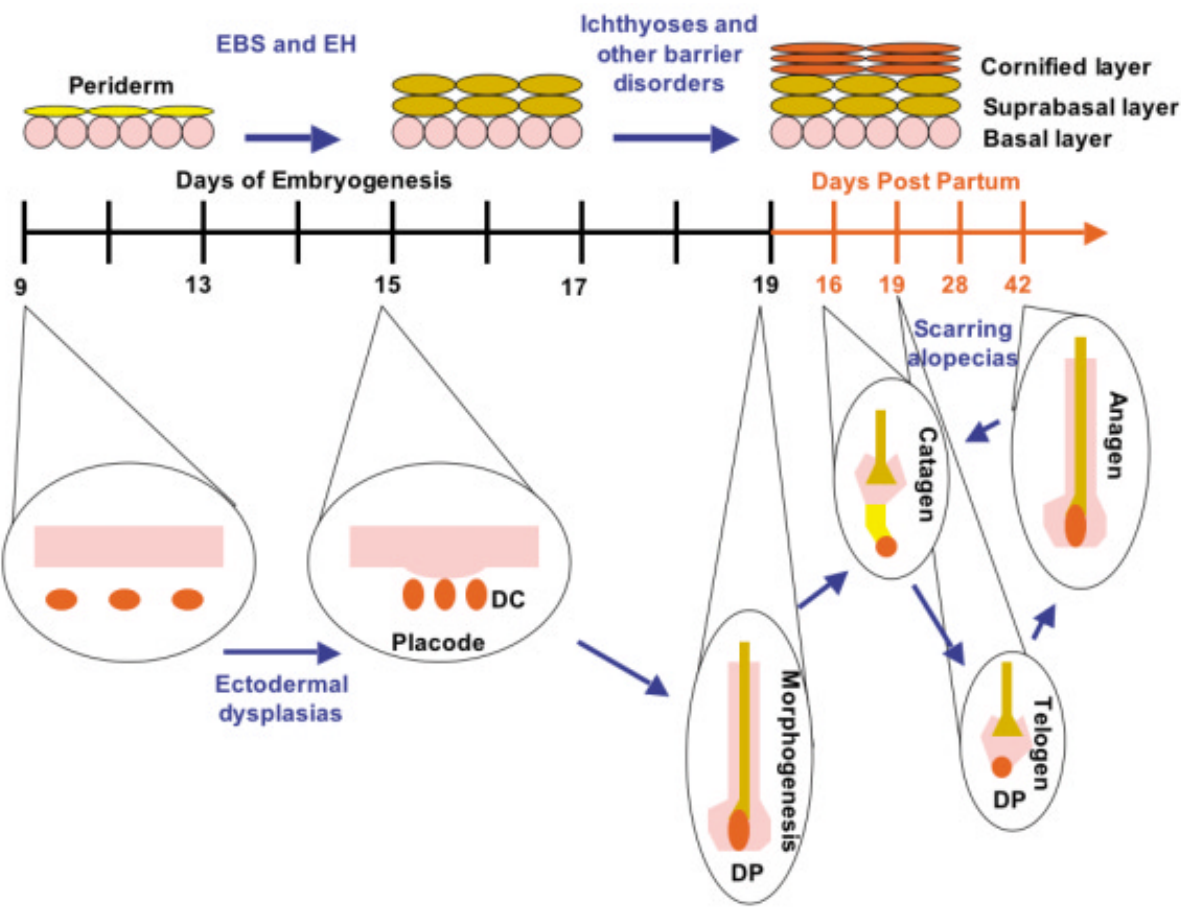

Fig. 1. An overview of epidermal development. In mice, the development of the epidermis and hair happens simultaneously just before and just after birth. Around E9, the first signals to make a placode are transduced to the epidermis. Placodes form around E15 and the formation of a hair follicle, morphogenesis continues until day 9 post partum, at which point the hair cycle starts with the the catagen-telogen transition around 16 days post partum. During the same time, the epidermis forms into an impermeable barrier from a single layer of cells around E9. An intact epidermis is formed, complete with cornified layer just prior to birth. The diseases which show their first effects at particular time points are shown in blue. DC, dermal condensate; DP, dermal papilla.
(MIM:305100) and autosomal recessive (MIM:224900). Both forms present with dry skin, absence of sweating as a result of lack of sweat glands, hypodontia and sparse hair on the body and head. Recently mutations in the genes responsible for several forms have been identified. Ectodysplasin I (EDA1), the gene mutated in $X$-linked HED, encodes for a $45 \mathrm{kDa}$ transmembrane protein and is a member of the tumour necrosis factor family (Kere et al., 1996; Elomaa et al., 2001). The C-terminal region has a characteristic death domain and a collagen-like domain through which is has been shown that EDA1 can trimerise. Also the extracellular domain the protein can be cleaved into a $20 \mathrm{kDa}$ soluble form (Elomaa tabbymice (Srivastava et al., 1997). The gene responsible for the autosomal recessive form is the receptor for EDA (EDAr), the human homologue of the gene mutated in downless mice and as family (Headon and Overbeek, 1999). Analogous to HED, the phenotypes of tabby and downless mice are identical, both autosomal recessive, with lack of hair behind the ear and on the tail, atly and display severe abnormalities in epidermal differentiation and appendage formation (Hu et al., 1999). Recently it has been shown that mice expressing a super repressor of NFKB have an identical phenotype to tabby and downless mice (Schmidt-Ullrich et al., 2001). In fact impaired NFKB signalling leads to HED with immunodeficiency (Doffinger et al., 2001).

Additionally an important member of the p53 family, p63, when knocked out in mice, produces a very similar phenotype to the IKK $\alpha$ knockout (Mills et al., 1999; Yang et al., 1999), with heterozygous germline mutations in the DNA binding domain of p63 being detected in the diseases EEC (ectrodactyly, ectodermal dysplasia and cleft lip/palate; MIM: 604292). Mutations in p63 are also detected in Hay Wells Syndrome or AEC (ankyloblepharon-ectodermal dysplasia-clefting) (MIM: 106260) (Celli et al., 1999, McGrath et al., 2001). The final piece of this puzzle fell into place with the very recent discovery of the gene encoded by the crinkled locus. The crinkled gene product is called Edaradd (for Edar-associated death domain). A missense mutation in the human homologue of crinkled, EDARADD has been discovered in a family presenting with HED (Headon et al., 2001). It appears that Edaradd binds the death domain present in EdaR and links Eda and EdaR to the NFkB/IKK complex downstream. (Fig. 2) EdaR and Eda are at the top of a genetic hierarchy that organizes the spacing and development of the placodes. In downless and tabby mice, 
$50 \%$ of the hair follicle types are missing, namely the zigzag and guard hairs, suggesting that the gene products of both tabbyand downlessare critical in the development of placodes that produce these hair follicle types. However the pathway is less important in the development of vibrissae, awl or tylotrich hairs. Mice null for the transcription factor Lef1 lacks whiskers, tooth and hair as well as other organs induced by mesenchymal-epithelial interactions, highlighting its overall importance in epidermal appendage development (Van Genderen et al., 1994). However a corresponding human disorder with mutations in LEF1 is yet to be identified. It is generally thought that the presence of soluble Eda may transduce a primary "make a placode" signal through the NF $\mathrm{KB} / \mathrm{l} \kappa \mathrm{B}$ signalling pathway, which is modulated by downstream signals from bone morphogenetic proteins, the $\beta$ catenin pathway and other soluble effectors such as sonic hedgehog. The understanding of the molecular basis of the ectodermal dysplasia, although far advanced by this work, is far from complete. Over 150 human diseases are termed ectodermal dysplasias and as yet very few genes responsible have been cloned. However particular families of genes responsible for other ectodermal dysplasias have been identified. Trichothiodystrophy (MIM:601675) is an autosomal recessive disease in which the hair is brittle due to a reduction in the sulphur content of the hair shaft. There is associated light sensitivity as well as neurological defects due to mutations in the helicases ERCC2 and ERCC3 (For example Weeda et al., 1997), which are also mutated in xeroderma pigmentosa groups $B$ and $D$ as well as Cockayne syndrome. Tricho-dento-osseus syndrome (MIM:190320) is a disease in which there is also increased bone density in the skull and long bones as well as hair and teeth defects, results from mutations in the homeodomain transcription factor DLX3 (Price et al., 1998). Finally, dyskeratosis congenita, $\mathrm{X}$-linked (MIM:305000), a recessive disease where the patient displays severe changes in the skin and the epidermal appendages, as well as leukoplakia of the mucosa, gastrointestinal lesions and bone marrow defects, is caused by mutations in the gene encoding the nuclear protein DKC1, thought to be important in telomere conservation (Heiss etal., 1998). These diseases illustrate that not only mutations in genes important in development lead to ectodermal dysplasias, but that genes important in DNA repair, when mutated, cause defects in tissues of high metabolic rate and proliferative capacity,, producing ectodermal dysplasia like symptoms. It is a challenge to cleanly categorise human disorders into those that cause developmental defects from those that cause epidermal defects in the adult epidermis. Two such crossover diseases are the fragile skin disorder (MIM:604536) and Papillon-Lefevre syndrome (MIM:245000). Both have characteristics of classic ectodermal dyplasias, with malformations of the hair and nails. Essentially, patients with fragile skin disorder present as a classical HED with additional skin fragility. Patients with this disease are compound heterozygotes for two mutations in plakophilin-1 (McGrath et al., 1997, Whittock et al., 2000). Plakophilin-1 is a protein that is present in the desmosomes of keratinocytes and as a member of the $\beta$ catenin/armadillo family genes, it is likely to have a duel structural and signalling role in keratinocytes, providing a possible explanation for both the ecto-

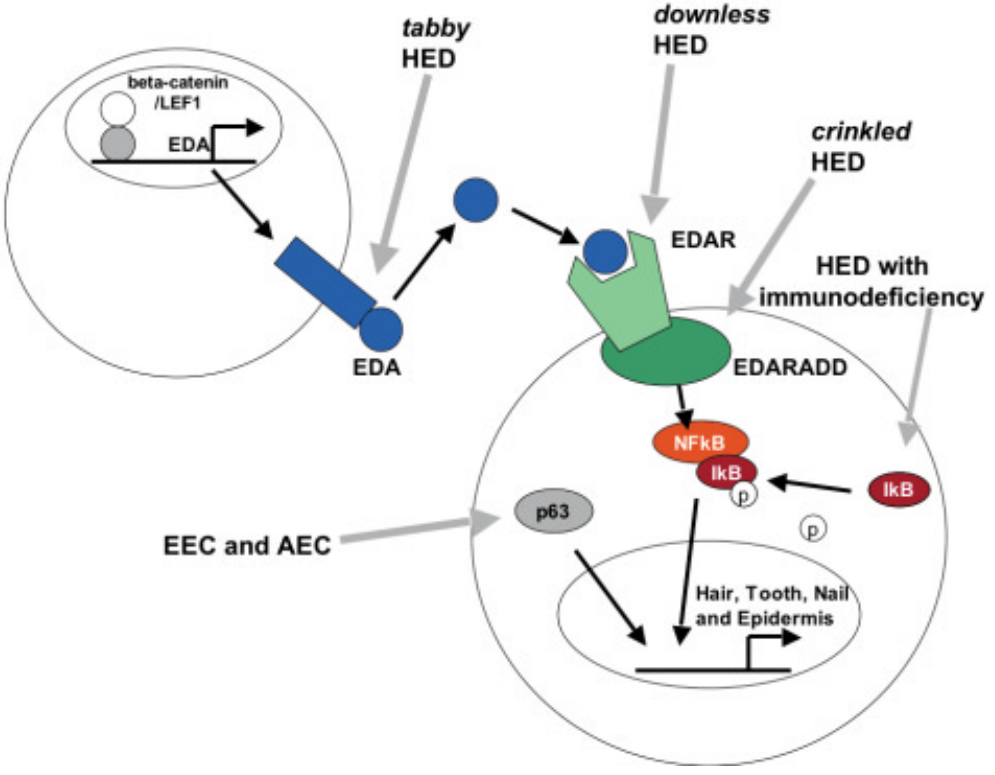

Fig. 2. A pathway to hypohidrotic ectodermal dysplasia. In the mouse, there are three loci which when mutated give rise to the tabby phenotype. In humans there are at least five diseases which lead to HED-like symptoms. All these genes e part of the ectodysplasin (EDA) pathway. EDA is expressed in response to EF1/ $\beta$ catenin and is expressed on the surface of cells. The extracellular domain n be proteolytically cleaved to produce a soluble signalling molecule which binds the ectodysplasin receptor (EDAR). EDAR interacts with the NFKB signalling complex via the EDARADD (crinkled) protein. Downstream signalling by $N F \kappa B, I \kappa B$ and $p 63$ leads to the expression of genes specific for the epidermis, hair, teeth and ails. Grey arrows indicate mouse mutations (italics) or human genetic diseases ssociated with the gene. AEC, ankyloblepharon-ectodermal dysplasia clefting yndrome; EEC, ectrodactyly-ectodermal dysplasia-cleft lip/palate; HED, pohidrotic ectordermal dysplasia.

dermal dysplasia and the skin fragility. Papillon-Lefevre patients have most of the features of classical ectodermal dysplasia, with hypotrichosis, nail fragility and periodonitis with associated early tooth loss. No sweat gland abnormalities have been reported in this disease. However there is a marked plantar hyperkeratosis that distinguishes it from classical ectodermal dysplasias. Patients with this disease have mutations in the lysosomal protease cathepsin C (Toomes et al., 1999). The function of cathepsin C in the epidermis is unclear, however, it does have a role in removing dipeptides from proteins during degradation and judging by the hyperkeratosis, it may have a role to play in keratin processing, as well as other important processes involving protein degradation during development.

\section{Attempting to make hair: the hedgehog pathway}

The skin is the most environmentally exposed organ of the human body. As such, somatic mutations accumulate in the epidermis far more than any other region of the body. As has been known for many years, mutations of genes involved in DNA repair can lead to skin cancer predisposition, the classical example being xeroderma pigmentosum (Cleaver et al., 1999) However in 1996, it was shown that one particular skin cancer predisposition syndrome is actually a developmental disorder. Gorlin syndrome 
(Naevoid Basal Cell Carcinoma Syndrome-NBCCS, MIM:109400) is a disorder that predisposes to the formation of basal cell carcinomas, that is tumours arising from the lowest layer of the epidermis. It manifests as multiple basal cell carcinomas, palmoplantar pits, indicative of incorrect expression of keratin, as well as developmental disorders including, but not limited to, bifid ribs and jaw cysts. The gene mutated in this autosomal dominant disorder is the human homologue of the drosophila segment polarity gene patched (Hahn et al., 1996; Johnson et al., 1996), part of the hedgehog signalling pathway (Fig. 3). Mutations not only in the tumour suppressor PATCHED, but also HSMO (the human homologue of drosophila smoothened) are associated with basal cell carcinoma (Gailiani et al., 1996; Reifenburger et al., 1998), as is over-expression of the protein GLI1 (Ghali et al., 1999). Although mutations in SHH are not seen in spontaneous basal cell carcinomas, a spectum of germline mutations cause holoprosencephely as well as phenomena sach as single incisors, indicative of patterning defects (Belloni et al., 1996, Nanni et al., 1999, Nanni et al., 2001, Onioli et al., 2001). Mouse models either expressing Shh or Gli1 in the basal layer of mouse epidermis or expressing mutant forms of Smoothened have the characteristics of basal cell carcinoma formation (Oro et al.,1997; Reifenburger et al., 1998; Nilsson et al., 2000) and more importantly their formation is not predicated on the mutation of either the oncogene Ras or the tumour suppressor p53.

So what is the function of the hedgehog pathway during development? In the mouse, both Patched and Shh are expressed in the hair germ and in the developing hair follicle in the epithelium, adjacent to the dermal papilla, as well as during hair follicle cycling where Shh is periodically expressed in the proliferative cells of the matrix. Tumors such as BCCs may well be

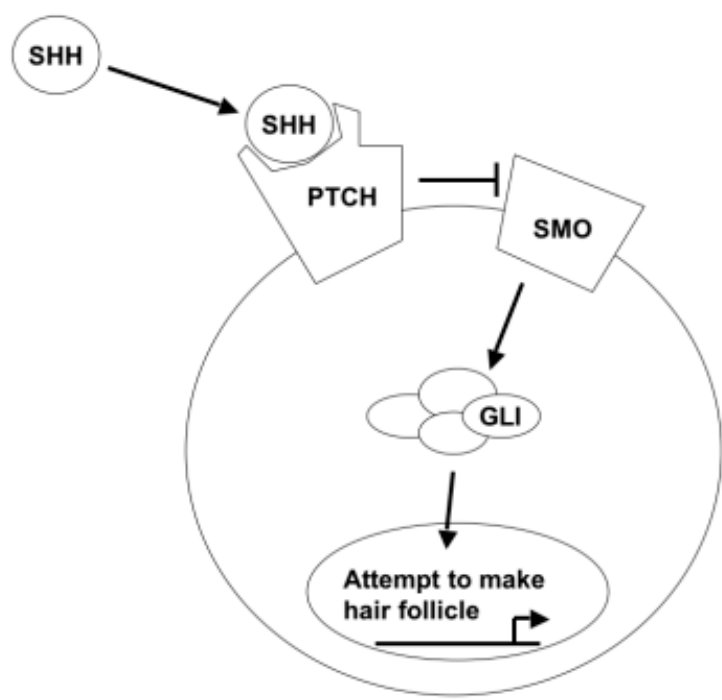

Fig. 3. The mammalian hedgehog pathway. Smoothened (SMO) can only signal to the protein complex containing Gli 1 when Sonic Hedgehog (SHH) is bound to Patched (PTCH). Under this circumstances, Gli 1 is translocated into the nucleus where it transcribes genes including PTCH which are responsible for the progression of the morphogenesis of the hair follicle, or when ectopically activated, causes the formation of a basal cell carcinoma. attempts to produce a hair follicle de-novoin the adult, a process first postulated by Pinkus over 40 years ago (Pinkus, 1959). The importance of Shh in hair cycling has been highlighted by ectopic expression of Shh in mouse epidermis using an adenovirus leading to the premature initiation of anagen in telogen hairs. Interestingly, ectopic expression of Shh during anagen leads to the premature stop of hair growth (Sato et al., 1999). Antibody treatments of embryos has revealed that inhibiting Shh function prevents morphogenesis of hair follicles beyond the hair germ stage, just after placode formation, with the viable offspring having no visible hair (Wang et al., 2000).

The classical ectodermal dysplasias, as well as fragile skin disorder and Gorlin syndrome, have contributed significantly to the field of epidermal development as it allows us to ascertain the sequence of signalling cascades that produces a mature hair follicle. So far the furthest upstream on the pathway are Eda and Edar, mutations in both genes lead to ectodermal dysplasia and they are essential for correct placode formation. Next $\beta$ catenin signalling (of which Plakophilin-1 is an important part), allows further development of the placode into the hair germ. Shh signalling is then required for the morphogenesis of hair follicles after hair germ formation.

\section{Diseases of epidermal differentiation: keratins and the cornified envelope}

The interfollicular epidermis can essentially be divided into three basic compartments. The basal epidermis where the proliferation occurs, the suprabasal epidermis, containing post-mitotic keratinocytes committed to differentiation and the cornified layer, where differentiated squames are produced. During this differentiation process there are tightly regulated programs of gene expression, one well studied example being the change in expression of keratins from the basal to the suprabasal layers. Keratinocytes produce large amounts of keratin for intermediate filaments, giving the keratinocytes their characteristic strength. There are human inherited disorders that disrupt the correct formation of keratin filaments. Mutations in the basal keratins 5 and 14 leads to the autosomal dominant disease epidermolysis bullosa simplex (Coulombe et al., 1991, MIM:131760), in which the epidermis blisters upon mild trauma, due to degeneration and rupture of basal keratinocytes. Mutations in the suprabasal keratin, keratin 10, cause the disease, epidermolytic hyperkeratosis, which causes a similar degeneration and blistering, but in the suprabasal layers of the epidermis (Rothnagel et al., 1992, MIM: 600648 ), Mutations the palmoplantar keratin 9, lead to the same phenotype being restricted to the palms and feet (MIM: 144200 , Rothnagel et al., 1995). Transgenic mouse models in which the human mutant keratin is expressed at the same level as the wildtype keratin, produce phenotypes analogous to the inherited diseases (Fuchs et al., 1992; Cao et al., 2001). In almost all cases of keratin mutations, the mutation interferes with the region of the keratin monomers required for proper assembly of intermediate filaments.Mutations in other keratins cause diseases that have more in common with ectodermal dysplasia than epidermolysis. Mutations in the suprabasal keratins 6 and 16 cause a disorder known as pachyonychia congenita (PC1, MIM: 167200), in which there are severe nail defects, as well as palmoplantar hyperkeratosis, follicular hyperkeratosis and oral leukoplakia (McLean et 
al., 1995). Mutations in keratin 17 cause a similar disorder (PC2, MIM: 167210), but without the leukoplakia and with the presence of neonatal teeth and cutaneous cysts (McLean et al., 1995). To further complicate the matter and to highlight the heterogeneity that can arise in human keratin diseases, mutations in keratin 17 can also cause a sebaceous cyst disease called steatocystoma multiplex (MIM: 184500). In some cases these two different diseases can be caused by the same mutation (Covello et al., 1998). Keratin 16 mutations can also cause focal non-epidermolytic palmoplantar keratoderma (MIM:600962) (Shamsher etal., 1995). The end point of epidermal differentiation is the squame, the production of which is tightly controlled in the granular and cornified layers. Mutations in the genes necessary for squame formation lead to the barrier deficiency diseases known as ichthyoses. The classical ichthyosis and the first for which a mutation was discovered is lamellar ichthyosis (MIM: 242300). In this disease, the patients suffer from a severe skin disorder in which there is an appearance of large scales (hence the name), associated with variable redness. The disease is caused by mutations in the keratinocyte transglutaminase gene (TG-1) (Russell et al., 1995). This gene is essential in the formation of squames as it allows the cross-linking of the various cornified envelope scaffold proteins to the plasma membrane. The mouse knockout for Tg-1 has a similar phenotype, with redness and scales and soon after birth the newborns exhibit significant trans-epidermal water loss (TEWL) and associated neonatal death (Matsuki et al., 1998). In fact there are other knockout mice and transgenics that display TEWL and the genes in question almost always have a role in maintaining barrier function. One naturally occurring mouse mutant, the recessive flaky tail mouse presents with a phenotype similar to the symptoms of another of these diseases, ichthyosis vulgaris (MIM: 146700). The mouse has large scales on the paws and tail, a marked decrease in the number of cells in the granular layer, as well as acanthosis and orthokeratotic hyperkeratosis, downward projections of the epidermis with hyperproliferation of the epidermis, however with normal keratin expression. These mice have reduced amounts of mature filaggrin and an increased amount of immature filaggrin, which is unable to be processed to produce keratohyalin granules, an essential constituent in the formation of squames (Presland et al., 2000). The flaky tail mouse also displays one other feature - constrictions in the tails and palm - which is one of the major characteristics of another autosomal dominant inherited disorder in humans, Vohwinkels syndrome, both the classical form presenting with deafness (MIM: 124500) or the variant form (MIM:604117). Vohwinkels syndrome is another generalised ichthyosis. Autoamputation of digits is often seen, the result of constrictions at joints in the fingers and toes, called pseudoainhum. Mutations in the cornified envelope protein loricrin are responsible for the variant form of Vohwinkles syndrome (Maestrini et al., 1996), whereas mutations in connexin 26, encoding a gap junction protein are responsible for classical Vohwinkels syndrome (Maestrini etal., 1999). Mutations in loricrin are also associated with the essentially identical disease progressive symmetric erythrokeratoderma (MIM:602036) Recent work using transgenic mice expressing these mutant forms of loricrin, has revealed that these mice have a phenotype very similar to both diseases. The mutant gene has a frameshift that allows the translation of another 22 amino acids that appear to encode a nuclear localization signal. The mutant loricrin accumulates in the nucleus and is therefore not deposited in the cornified envelope (Suga et al., 2000). Mating the knockout to the transgenic mouse causes an increase in severity of the phenotype. The mutant loricrin appears to have a dominant negative effect that is dose dependent and prevents the proper formation of anucleate squames. Keratins also appear to have a role to play in the ichthyosiform diseases. As mentioned earlier, all the other genodermatoses involving mutations in keratins to date, are due to mutations in the beginning and end of the rod area of the protein, important for proper assembly of the keratin filaments. However, a novel mutation in the variable tail region of keratin 1 appears to be the cause of a severe hyperkeratosis called ichthyosis hystrix Curth-Macklin (MIM:146590). This keratin mutation impairs the ability of loricrin to be translocated to the desmosomes in preparation for cornified envelope assembly (Sprecher et al., 2001). Keratin $2 e$ is expressed late in keratinocyte differentiation. A spectrum of different mutations leads to another ichthyosiform disease, ichthyosis bullosa of Siemens (Rothnagel et al., 1994, Kremer et al., 1994)

\section{The desmosome and diseases of epidermal integrity}

The epidermis is under considerable stress, both external and mechanical. To protect the keratinocytes from damage they are connected by an extensive network of cell-cell junctions called desmosomes. The fragile skin disorder due to plakophilin-1 mutations described earlier is one disease caused by abnormalities in the desmosomes. There are several inherited diseases that are caused by mutations in genes encoding componants of the desmosome, which usually result is skin fragility phenotypes. Striate palmoplantar keratoderma is a disease in which patients have hyperkeratotic bands on the plams and the feet. The disease is inherited in an autosomal dominant fashion and is the result of haploinsufficiency of desmoplakin, or the desmosomal cadherin, desmoglein 1, brought about by the deletion of the $\mathrm{N}$-terminal portion. (Armstrong et al., 1999, Rickman et al., 1999, Whittock et al., 1999). By contrast, when the desmoplakin gene exhibits recessive mutations, or compound heterozygosity, the result is a keratoderma with wooly hair and associated cardiomyopathy commonly known as Naxos disease (MIM:601214). Patients with Naxos disease can also have mutations in the armadillo repeat containing ( $\beta$ catenin like) gene plakoglobin (Norgett et al., 2000). At least one other locus for Naxos disease exists, as shown in a recent report, excluding linkage to either of the known genes (Djabali et al., 2002)

As with some of the ectodermal dysplasias, it's not entirely clear why mutations in genes should lead to skin phenotypes. Two such diseases are Hailey-Hailey (MIM:169600) and Darier disease (MIM:124200). Hailey-Hailey Disease presents as a recurrent eruption of vesicles and bullae at the neck, groin and axillary regions, while patients with Darier disease have keratotic papules associated with seborrheic areas. Both have subclincal keratinocyte cell-cell interaction abnormalities. Histological studies have revealed acantholysis, that is separation of the keratinocytes, in the suprabasal region of the epidermis. Mutations in the sarco/endoplasmic reticulum calcium pump ATP2A2 are responsible for Darier disease, while mutations in ATP2C1 are responsible for the Hailey-Hailey disease (Sudbrak et al., 2000; Sakuntabhai et al., 1999). What has become clear by the 
variety of gene mutations that cause epidermal defects is that the differentiating epidermis is a tightly controlled tissue in which the slightest perturbation can cause severe abnormalities.

\section{Diseases of hair cycling and hair shaft formation}

Abnormality of the hair follicle is one area in which knowledge about mouse mutations far exceeds the human diseases. The presence of vibrissae and the synchronisation of the hair cycle are the two main reasons that make it easier to detect subtle changes in hair follicle phenotype. Having said this, many human inherited hair defects exist which fall into two main categories, defects in hair shaft formation and defects in hair cycling. Hair cycling is a specialized developmental process dependent on the continued interaction between the mesenchymal tissue, the dermal papilla and corresponding epithelial cells either the so called bulge cells of the hair follicle, or the rapidly proliferating matrix keratinocytes. Hair shaft growth is a result of the proliferation of the matrix and is an exquisitely organized combination of patterning and differentiation that leads to the formation of a mature hair shaft consisting of six concentrically arranged cylinders of specially differentiated keratinocytes.

The hair shaft consists of at least 100 proteins, mutations in some of which lead to hair shaft malformations. An example of such a disease is monilethrix (MIM:158000), in which patients have sparse visible hair due to fragility. Microscopic analysis of the hair reveals characteristic beading down the length of the shaft, which presumably contributes to the comparatively easy breakage of the shaft. Mutations in two hair keratins to date have been implicated in this disease, hair keratin 6 and more recently hair keratin 1 (Winter et al., 1997a; Winter et al., 1997b). Both keratins are expressed in the cortex cells of the hair follicles and presumably contribute to the physical strength of the mature hair shaft. Like the other keratinopathies, monilethrix is a dominantly inherited disease reflecting the mechanism of action of keratin mutations in intermediate filament assembly.

The recessive nude phenotype in the mouse displays a congenitial absence of hair as well as severe immunological deficiency. The analogous human disease (MIM:601705) displays an identical phenotype. In fact the hair follicles are present, but the hair shafts are abnormal and unable to penetrate the surface. Mutations in the winged helix gene Whn (winged helix nude, now called Foxn1) are responsible for the mutant mouse as well as the associated human disorder (Brissette et al., 1996; Frank et al., 1999). Although how mutations in the Whn gene contribute to the disease is not yet known, it is thought that the phenotype is due to a problem with the correct expression of keratins in the differentiating hair shaft. This leads to a characteristic convoluted upper hair shaft that does not have the ability to penetrate the skin surface.

There are a large number of disorders that lead to hair shaft malformation. Other diseases including Netherton syndrome (MIM:256500), an autosomal recessive ichthyosis, exhibits a characteristic hair shaft malformation known as trichorrhexis invaginata (bamboo hair). Mutations in the SPINK5 gene, coding for the serine protease inhibitor LEKTI, have recently been detected in Netherton syndrome (Chavanas et al., 2000), although rather like WHN, the function of this gene in the formation of the hair shaft is not clear. Mutations in a copper transporter gene are responsible for the $\mathrm{X}$-linked disease Menkes kinky hair syndrome (MIM:309400, summarised by Davies, 1993), where patients have sparse hair as well as neurological dysfunction. Microscopic analysis reveals pili torti (twisted hair), trichorrhexis nodosa (focal fractures in the hair shaft) and hypopigmented hair. Again the biological function of the copper transporter gene in normal hair shaft formation is unclear. Recently a link between cell-cell adhesion and the integrity of the hair shaft has been elucidated in the discovery of the gene mutated in the lancolate mouse and rat and the corresponding human disease, localised autosomal recessive hypotrichosis, $\mathrm{LAH}$, which causes the production of large blobs in the growing hair shaft that break the hair shaft as it penetrates the epidermis and produces a "lance-head" appearance (Kjulic et al., 2003; Jahoda et al., 2004). In all these cases mutations in a novel desmosomal cadherin, desmoglein 4 (Kjulic et al., 2004 and Whittock and Bower, 2003), causes severe abnormalities in cell-cell adhesion in the hair follicle, as well as mild hyperplasia in the interfollicular epidermis, further reinforcing the requirement for correct cell-cell contacts in the maintainence of skin and hair.

As mentioned earlier, after morphogenesis the hair follicle proceeds through cycles of three distinct phases. First an active growth phase or anagen, then an involution phase, called catagen, which involves the dermal papilla, the mesenchymal organizing centre of the hair follicle moving up to the bulge region and finally a quiesent phase known as telogen. Disorders in anagen would conceivably lead to a change in hair length. This is the case in the angora mouse, where there is $50 \%$ longer hair growth due to an $50 \%$ longer anagen phase as a result of a mutation in the fibroblast growth factor 5 gene (Fgf5), which delays the onset of catagen (Hebert et al., 1994). As mentioned earlier, mutations affecting anagen are easy to detect in the mouse with its synchronised hair cycles. However angora mutations in humans would be difficult to detect, as the anagen phase is very long in humans from 3 months to 6 years. Very rarely hair overgrowth syndromes, or hypertrichoses, occur in humans, however the molecular basis of these hypertrichoses is unknown.

During hair follicle cycling, after the active growth phase, a program or keratinization of the hair shaft starts, which ultimately forms the club hair, which is anchored in the hair follicle during telogen. There are human diseases in which club hairs easily fall out, such as loose anagen syndrome or telogen effuvium (Sinclair et al., 1999, Rebora et al., 1997). A genetic basis for these diseases is unknown. Insight has come from mice null for desmosomal cadherin demoglein 3 (dsg3), the pemphigus vulgaris antigen. In addition to a pemphigus vulgaris phenotype, the mice showed early loss of hair during telogen (Koch et al., 1998). In wildtype and human telogen follicles, there is intense staining with a antibody to dgs 3 on the surface of keratinocytes in contact with the club hair. This is the first evidence to date of a gene responsible for anchoring the hair during telogen.

Diseases that affect the ability of the hair follicle to progress through catagen would show a similar phenotype in both the mouse and humans. Thorough investigation of the hairless (hr) mouse has shown that the alopecia associated with the phenotype is a result of a defect in catagen (Panteleyev et al., 1999). In the hairless mouse, there is an increase in the degree of apoptosis in the hair follicle at the onset of catagen, destroying the epithelial sheath that allows the dermal papilla to return to the bulge of the 
hair follicle. As a result the dermal papilla is stranded in the deep dermis and the hair follicle is unable to continue to cycle. Large openings in the upper region of the hair follicle, called utricles, form and in some cases these produce large cysts. The follicle is never again able to cycle and loses the ability to produce hair. The corresponding human disorder is known (MIM:209500) affecting all hairs. As would be expected, mutations in the HR gene were found to be responsible for the disease in a large number of families (Ahmed et al., 1998, Ahmed et al., 1999, Ahmed et al., 1999, Aita et al., 2000, Zlotogorski et al., 1998). Also, akin to the two forms of HED, there is a similar disease due to mutations in the vitamin D receptor (VDR) in humans, as well as in mice null for either the VDR or the retinoid $\mathrm{X}$ receptor $\alpha$ subunit (Miller et al., 2001, Li et al., 1997, Li et al., 2001).

\section{Conclusions, future directions, complex traits}

The exploding field of trangenic mice and more recently the advent of tissue specific transgenics and knockout mice has allowed the manipulation of not only genes implicated in human monogenetic disorders (such as the keratins) but also the investigation of genes that are normally critical for the development of the organism. The combination of these approaches as well as mouse mutants both identified and unidentified, has and will continue to reveal large amounts of information on the development and differentiation of the epidermis and its appendages, as well as inherited disorders. There are still many mouse mutants that have abnormalities in skin and hair as well as hair cycling. Many of these mutants have no human counterpart to date, but the hope is that important connections can be made between mouse and man with the near completion of the sequence of both genomes will continue to lead to the identification of new genes. The use of comparative genomics approaches allows the linking of mouse mutations to a syntenic region in the human and vice versa.

Psoriasis and alopecia are at a are common diseases, the first a disease of abnormal differentiation of the epidermis, the second the reversible destruction of structures of the hair follicle. Both diseases exhibit hallmarks of inheritance as complex genetic traits (Aita et al., 1999, Barker 2000). The power of mouse models has failed in trying to determine a basis of these diseases as they are impossible to model in congenic mouse strains. Alternative approaches must be used to zero in on the cause of diseases such as these. Classical approaches such as linkage analysis and analysis of affected pairs of siblings to discover shared alleles are used to discover regions of the genome associated, linkage to specific HLA alleles has also been investigated. However this is still a long way from identifying the gene(s) responsible for either psoriasis or alopecia areata. Coupling these approaches with the comprehensive expression analysis afforded by microarray technology will enable the detection of differentially expressed families of genes in the regions of interest and has already been perform to some degree in alopecia areata. In addition, widescale screening of SNPs, single nucleotide polymorphisms, particularly in the coding regions of genes could lead to an elucidation of the genotype of individuals with the disease and maybe recapitulation of the disease in the mouse.

To conclude, the last five years have been interesting times in the discovery of the molecular basis of many inherited disorders.
The benefit that this has had to the understanding of the basic biology of the skin and its appendages cannot be over-emphasised. In the next five years, there will no doubt be an even greater body of knowledge accrued on the subject, as the discovery of mutations in monogenetic disorders, more accurate chromosomal linkage and the discovery of susceptibility loci in complex disorders continues.

\section{References}

AHMAD W, FAIYAZ UL HAQUE M, BRANCOLINI V, TSOU HC, UL HAQUE S, LAM $\mathrm{H}$, AITA VM, OWEN J, DEBLAQUIERE M, FRANK J, CSERHALMI-FRIEDMAN PB, LEASK A, MCGRATH JA, PEACOCKE M, AHMAD M, OTT J, CHRISTIANO AM. (1998) Alopecia universalis associated with a mutation in the human hairless gene. Science 279: 720-4.

AHMAD W, NOMURA K, MCGRATH JA, HASHIMOTO I, CHRISTIANO AM. (1999) A homozygous nonsense mutation in the zinc-finger domain of the human hairless gene underlies congenital atrichia. J Invest Dermatol. 113: 281-3.

AHMAD W, ZLOTOGORSKI A, PANTELEYEV AA, LAM H, AHMAD M, UL HAQUE MF, ABDALLAH HM, DRAGAN L, CHRISTIANO AM. (1999) Genomic organization of the human hairless gene $(\mathrm{HR})$ and identification of a mutation underlying congenital atrichia in an Arab Palestinian family. Genomics 56:141-8.

AITA VM, CHRISTIANO AM, GILLIAM TC. (1999) Mapping complex traits in diseases of the hair and skin. Exp Dermatol. 8:439-52

AITA VM, AHMAD W, PANTELEYEV AA, KOZLOWSKA U, KOZLOWSKAA, GILLIAM TC, JABLONSKA S, CHRISTIANO AM. (2000) A novel missense mutation (C622G) in the zinc-finger domain of the human hairless gene associated with congenital atrichia with papular lesions. Exp Dermatol. 9:157-62.

ARMSTRONG DK, MCKENNA KE, PURKIS PE, GREEN KJ, EADY RA, LEIGH IM, HUGHES AE. (1999). Haploinsufficiency of desmoplakin causes a striate subtype of palmoplantar keratoderma. Mol Genet 8:143-8.

BARKER JN.(2001). Genetic aspects of psoriasis. Clin Exp Dermatol. 26(4): 321-5 BELLONI E, MUENKE M, ROESSLER E, TRAVERSO G, SIEGEL-BARTELT J, FRUMKIN A,MITCHELL HF, DONIS-KELLER H, HELMS C, HING AV, HENG HH, KOOP B, MARTINDALE D, ROMMENS JM, TSUI LC, SCHERER SW. (1996) Identification of Sonic hedgehog as a candidate gene responsible for holoprosencephaly. Nat Genet 14:353-6.

BRISSETTE JL, LI J, KAMIMURA J, LEE D, DOTTO GP. (1996). The product of the mouse nude locus, Whn, regulates the balance between epithelial cell growth and differentiation. Genes Dev 10: 2212-21.

CAO T, LONGLEY MA, WANG XJ, ROOP DR. (2001). An inducible mouse model for epidermolysis bullosa simplex: implications for gene therapy. $J \mathrm{Cell} \mathrm{Biol}$ 152:651-6.

CELLI J, DUIJF P, HAMEL BC, BAMSHAD M, KRAMER B, SMITS AP, NEWBURY ECOBR, HENNEKAMRC, VANBUGGENHOUT G, VANHAERINGENA, WOODS CG, VAN ESSEN AJ, DE WAAL R, VRIEND G, HABER DA, YANG A, MCKEON F, BRUNNER HG, VAN BOKHOVEN H. (1999) Heterozygous germline mutations in the p53 homolog p63 are the cause of EEC syndrome. Cell. 99:143-53.

CHAVANAS S, BODEMER C, ROCHAT A, HAMEL-TEILLAC D, ALI M, IRVINE AD, BONAFE JL, WILKINSON J, TAIEB A, BARRANDONY, HARPER JI, DE PROST Y, HOVNANIAN A.(2000). Mutations in SPINK5, encoding a serine protease inhibitor, cause Netherton syndrome. Nat Genet 25:141-2.

CLEAVER JE, THOMPSON LH, RICHARDSON AS, STATES JC. (1999). A summary of mutations in the UV-sensitive disorders: xeroderma pigmentosum, Cockayne syndrome and trichothiodystrophy. Hum Mutat 14: 9-22.

COULOMBE PA, HUTTON ME, LETAI A, HEBERT A, PALLER AS, FUCHS E. (1991). Point mutations in human keratin 14 genes of epidermolysis bullosa simplex patients: genetic and functional analyses. Cel/66: 1301-11.

COVELLO SP, SMITH FJ, SILLEVIS SMITT JH, PALLER AS, MUNRO CS, JONKMAN MF, UITTOJ, MCLEANWH. (1998). Keratin 17 mutations cause either steatocystoma multiplex or pachyonychia congenita type 2. Br J Dermato/139: 475-80.

DAVIES K. (1993). Cloning the Menkes disease gene. Nature 361: 98.

DJABALI, K., MARTINEZ-MIR, A., HOREV, L., CHRISTIANO, A.M. and ZLOTOGORSKI, A. (2002) Evidence for extensive locus heterogeneity in Naxos disease. J Invest Dermatol. 118: 557-60. 
DJABALI K, MARTINEZ-MIR A, HOREV L, KLAPHOLZ L, CHRISTIANO AM, ZLOTOGORSKI A. (In press). Evidence for extensive locus heterogeneity for Naxos Disease, J Invest Dermatol.

DOFFINGER R, SMAHI A, BESSIA C, GEISSMANN F, FEINBERG J, DURANDY A, BODEMER C, KENWRICK S, DUPUIS-GIROD S, BLANCHE S, WOOD P, RABIA SH, HEADON DJ, OVERBEEK PA, LE DEIST F, HOLLAND SM, BELANI K, KUMARARATNE DS, FISCHER A, SHAPIRO R, CONLEY ME, REIMUND E, KALHOFFH, ABINUNM, MUNNICH A, ISRAELA, COURTOIS G, CASANOVAJL. (2001). X-linked anhidrotic ectodermal dysplasia with immunodeficiency is caused by impaired NF-kappaB signaling. Nat Genet. 27: 277-85.

ELOMAA O, PULKKINEN K, HANNELIUS U, MIKKOLA M, SAARIALHO-KERE U, KERE J (2001). Ectodysplasin is released by proteolytic shedding and binds to the EDAR protein. Hum Mol Genet 10: 953-62.

FRANK J, PIGNATA C, PANTELEYEV AA, PROWSE DM, BADEN H, WEINER L, GAETANIELLO L, AHMAD W, POZZI N, CSERHALMI-FRIEDMAN PB, AITA VM, UYTTENDAELE H, GORDON D, OTT J, BRISSETTE JL, CHRISTIANO AM. (1999). Exposing the human nude phenotype. Nature 398:473-4.

FUCHS E, ESTEVES RA, COULOMBE PA. (1992). Transgenic mice expressing a mutant keratin 10 gene reveal the likely genetic basis for epidermolytic hyperkeratosis. (1992). Proc Nat/ Acad Sci USA 89: 6906-10.

GAILANI MR, STAHLE-BACKDAHL M, LEFFELL DJ, GLYNN M, ZAPHIROPOULOS PG, PRESSMAN C, UNDEN AB, DEAN M, BRASH DE, BALE AE, TOFTGARD R. (1996). The role of the human homologue of Drosophila patched in sporadic basal cell carcinomas. Nat Genet 14: 78-81.

GHALI L, WONG ST, GREEN J, TIDMAN N, QUINN AG. (1999). Gli1 protein is expressed in basal cell carcinomas, outer root sheath keratinocytes and a subpopulation of mesenchymal cells in normal human skin. J Invest Dermato/113: 595-9.

HAHN H, WICKING C, ZAPHIROPOULOUS PG, GAILANI MR, SHANLEY S, CHIDAMBARAM A, VORECHOVSKY I, HOLMBERG E, UNDEN AB, GILLIES S, NEGUS K, SMYTH I, PRESSMAN C, LEFFELL DJ, GERRARD B, GOLDSTEIN AM, DEAN M, TOFTGARD R, CHENEVIX-TRENCH G, WAINWRIGHT B, BALE AE. (1996). Mutations of the human homolog of Drosophila patched in the nevoid basal cell carcinoma syndrome. Cel/85: 841-51.

HARDMAN MJ, SISI P, BANBURY DN, BYRNE C. (1998). Patterned acquisition of skin barrier function during development. Development 125:1541-52.

HEADON DJ, OVERBEEK PA. (1999). Involvement of a novel Tnf receptor homologue in hair follicle induction. Nat Genet22: 370-4.

HEADONDJ, EMMAL SA, FERGUSONBM, TUCKERAS, JUSTICEMJ, SHARPE PT ZONANA J, OVERBEEK PA. (2001). Gene defect in ectodermal dysplasia implicates a death domain adapter in development. Nature 414:913-6.

HEBERT JM, ROSENQUIST T, GOTZ J, MARTIN GR. (1994). FGF5 as a regulator of the hair growth cycle: evidence from targeted and spontaneous mutations. Cel/78: 1017-25.

HEISS NS, KNIGHT SW, VULLIAMY TJ, KLAUCK SM, WIEMANN S, MASON PJ, POUSTKA A, DOKAL I. (1998). X-linked dyskeratosis congenita is caused by mutations in a highly conserved gene with putative nucleolar functions. Nat Genet 19: 32-8.

HUY, BAUD V, DELHASE M, ZHANG P, DEERINCK T, ELLISMAN M, JOHNSON R, KARIN M. (1999) Abnormal morphogenesis but intact IKK activation in mice lacking the IKKalpha subunit of IkappaB kinase. Science 284: 316-20.

JAHODA, C.A., KLJUIC, A., O'SHAUGHNESSY, R., CROSSLEY, N., WHITEHOUSE, C.J., ROBINSON, M., REYNOLDS, A.J., DEMARCHEZ, M., PORTER, R.M., SHAPIRO, L. and CHRISTIANO, A.M. (2004) The lanceolate hair rat phenotype results from a missense mutation in a calcium coordinating site of the desmoglein 4 gene. Genomics 83: 747-56.

JOHNSON RL, ROTHMAN AL, XIE J, GOODRICH LV, BARE JW, BONIFAS JM, QUINN AG, MYERS RM, COX DR, EPSTEIN EH JR, SCOTT MP. (1996). Human homolog of patched, a candidate gene for the basal cell nevus syndrome. Science 272: 1668-71.

KERE J, SRIVASTAVA AK, MONTONEN O, ZONANA J, THOMAS N, FERGUSONB, MUNOZ F, MORGAN D, CLARKE A, BAYBAYAN P, CHEN EY, EZER S, SAARIALHO-KERE U, DE LA CHAPELLE A, SCHLESSINGER D (1996). X-linked anhidrotic (hypohidrotic) ectodermal dysplasia is caused by mutation in a novel transmembraneprotein. Nat Genet 13: 409-16.

KLJUIC, A., BAZZI, H., SUNDBERG, J.P., MARTINEZ-MIR, A., O'SHAUGHNESSY, R., MAHONEY, M.G., LEVY, M., MONTAGUTELLI, X., AHMAD, W., AITA, V.M., GORDON, D., UITTO, J., WHITING, D., OTT, J., FISCHER, S., GILLIAM, T.C.,
JAHODA, C.A., MORRIS, R.J., PANTELEYEV, A.A., NGUYEN, V.T. and CHRISTIANO, A.M. (2003) Desmoglein 4 in hair follicle differentiation and epidermal adhesion: evidence from inherited hypotrichosis and acquired pemphigus vulgaris. Cel/113: 249-60

KREMER $\mathrm{H}$, ZEEUWEN P, MCLEAN WH, MARIMAN EC, LANE EB, VAN DE KERKHOF CM, ROPERS HH, STEIJLEN PM.(1994) Ichthyosis bullosa of Siemens is caused by mutations in the keratin 2e gene. J Invest Dermatol. 103: 286-9.

KOCH PJ, MAHONEY MG, COTSARELIS G, ROTHENBERGER K, LAVKER RM STANLEY JR. (1998). Desmoglein 3 anchors telogen hair in the follicle. J Cell SCi. 111: 2529-37.

LI YC, PIRRO AE, AMLING M, DELLING G, BARON R, BRONSON R, DEMAY MB. (1997). Targeted ablation of the vitamin $D$ receptor: an animal model of vitamin D-dependent rickets type II with alopecia. Proc Nat/ Acad Sci USA 94: 9831-5.

LIM, CHIBAH, WAROT X, MESSADDEQN, GERARD C, CHAMBON P, METZGER D.(2001) RXR-alpha ablation in skin keratinocytes results in alopecia and epidermal alterations. Development 128: 675-88.

MAESTRINI E, MONACO AP, MCGRATH JA, ISHIDA-YAMAMOTO A, CAMISA C, HOVNANIAN A, WEEKS DE, LATHROP M, UITTO J, CHRISTIANO AM. (1996). A molecular defect in loricrin, the major component of the cornified cell envelope, underlies Vohwinkel's syndrome. Nat Genet 13: 70-7.

MAESTRINI E, KORGE BP, OCANA-SIERRA J, CALZOLARI E, CAMBIAGHI S, SCUDDER PM, HOVNANIAN A, MONACO AP, MUNRO CS. (1999). A missense mutation in connexin26, D66H, causes mutilating keratoderma with sensorineural deafness (Vohwinkel's syndrome) in three unrelated families. Hum Mol Genet 8:1237-43.

MATSUKI M, YAMASHITA F, ISHIDA-YAMAMOTO A, YAMADA K, KINOSHITA C FUSHIKI S, UEDA E, MORISHIMA Y, TABATA K, YASUNO H, HASHIDA M, IIZUKA H, IKAWA M, OKABE M, KONDOH G, KINOSHITA T, TAKEDA J, YAMANISHI K. (1998) Defective stratum corneum and early neonatal death in mice lacking the gene for transglutaminase 1 (keratinocyte transglutaminase). Proc Natl Acad Sci USA 95:1044-9.

MCGRATH JA, MCMILLAN JR, SHEMANKO CS, RUNSWICK SK, LEIGH IM, LANE EB, GARROD DR, EADY RA. (1997). Mutations in the plakophilin 1 gene result in ectodermal dysplasia/skin fragility syndrome. Nat Genet. 17: 240-4.

MCGRATH JA, DUIJF PH, DOETSCH V, IRVINE AD, DE WAAL R, VANMOLKOT KR, WESSAGOWIT V, KELLY A, ATHERTON DJ, GRIFFITHS WA, ORLOW SJ, VAN HAERINGEN A, AUSEMS MG, YANG A, MCKEON F, BAMSHAD MA, BRUNNER HG, HAMEL BC, VAN BOKHOVEN H. (2001). Hay-Wells syndrome is caused by heterozygous missense mutations in the SAM domain of p63. Hum Mol Genet. 10: 221-9.

MCLEAN WH, RUGG EL, LUNNY DP, MORLEY SM, LANE EB, SWENSSON O, DOPPING-HEPENSTAL PJ, GRIFFITHS WA, EADY RA, HIGGINS C, et al.(1995). Keratin 16 and keratin 17 mutations cause pachyonychia congenita. Nat Genet 9: 273-8.

MILLER J, DJABALIK, CHEN T, LIUY, IOFFREDA M, LYLE S, CHRISTIANO AM, HOLICK M, COTSARELIS G. (2001). Atrichia caused by mutations in the vitamin $D$ receptor gene is a phenocopy of generalized atrichia caused by mutations in the hairless gene. $J$ Invest Dermato/117:612-7.

MILLS AA, ZHENG B, WANG XJ, VOGEL H, ROOP DR, BRADLEY A. (1999). p63 is a p53 homologue required for limb and epidermal morphogenesis. Nature 398: 708-13.

NANNI L, MING JE, BOCIAN M, STEINHAUS K, BIANCHI DW, DIE-SMULDERS C, GIANNOTTI A, IMAIZUMI K, JONES KL, CAMPO MD, MARTIN RA, MEINECKE P, PIERPONT ME, ROBINNH, YOUNG ID, ROESSLERE, MUENKE M.(1999). The mutational spectrum of the sonic hedgehog gene in holoprosencephaly: $\mathrm{SHH}$ mutations cause a significant proportion of autosomal dominant holoprosencephaly. Hum Mol Genet. 8: 2479-88.

NANNI L, MING JE, DU Y, HALL RK, ALDRED M, BANKIER A, MUENKE M. (2001). SHH mutation is associated with solitary median maxillary central incisor: a study of 13 patients and review of the literature. J Med Genet 102: 1-10.

NILSSONM, UNDEN AB, KRAUSE D, MALMQWISTU, RAZAK, ZAPHIROPOULOS PG, TOFTGARD R. (2000). Induction of basal cell carcinomas and trichoepitheliomas in mice overexpressing GLI-1. Proc Nat/ Acad Sci USA 97: 3438-43.

NORGETT EE, HATSELL SJ, CARVAJAL-HUERTA L, CABEZAS JC, COMMON J, PURKIS PE, WHITTOCK N, LEIGH IM, STEVENS HP, KELSELL DP. (2000). Recessive mutation in desmoplakin disrupts desmoplakin-intermediate filament 
interactions and causes dilated cardiomyopathy, woolly hair and keratoderma. Hum Mol Genet 9: 2761-6.

ORO AE, HIGGINS KM, HU Z, BONIFAS JM, EPSTEIN EH JR, SCOTT MP.(1997). Basal cell carcinomas in mice overexpressing sonic hedgehog. Science 276: 817-21.

ORIOLI IM, CASTILLA EE, MING JE, NAZER J, BURLE DE AGUIAR MJ, LLERENA JC, MUENKE M. (2001). Identification of novel mutations in SHH and ZIC2 in a South American (ECLAMC) population with holoprosencephaly. Hum Genet. 109: 1-6.

PANTELEYEV AA, BOTCHKAREVA NV, SUNDBERG JP, CHRISTIANO AM, PAUS R. (1999). The role of the hairless (hr) gene in the regulation of hair follicle catagen transformation. Am J Patho/155: 159-71.

PINKUS H. (1959). Skin cancer and basic research in dermatology. J Invest Dermato/33: 171-79

PISPA, J. and THESLEFF, I. (2003). Mechanisms of ectoderrmal organogenesis. Dev. Biol. 262: 195-205

PRESLAND RB, BOGGESS D, LEWIS SP, HULL C, FLECKMAN P, SUNDBERG JP. (2000) Loss of normal profilaggrin and filaggrin in flaky tail (ft/ft) mice: an animal model for the filaggrin-deficient skin disease ichthyosis vulgaris. J/nvest Dermato/115: 1072-81.

PRICE JA, WRIGHT JT, KULA K, BOWDEN DW, HART TC. (1998). A common DLX3 gene mutation is responsible for tricho-dento-osseous syndrome in Virginia and North Carolina families. J Med Genet 35: 825-8.

REBORA A. (1997) Telogen effluvium. Dermatology 195: 209-12

REIFENBERGER J, WOLTER M, WEBER RG, MEGAHED M, RUZICKA T, LICHTER P, REIFENBERGER G. (1998) Missense mutations in SMOH in sporadic basal cell carcinomas of the skin and primitive neuroectodermal tumors of the central nervous system. Cancer Res 58: 1798-803.

RICKMAN L, SIMRAK D, STEVENS HP, HUNT DM, KING IA, BRYANT SP, EADY RA, LEIGH IM, ARNEMANN J, MAGEE AI, KELSELL DP, BUXTON RS.(1999). $\mathrm{N}$-terminal deletion in a desmosomal cadherin causes the autosomal dominant skin disease striate palmoplantar keratoderma. Hum Mol Genet. 8: 971-6.

ROTHNAGEL JA, DOMINEY AM, DEMPSEY LD, LONGLEY MA, GREENHALGH DA, GAGNE TA, HUBER M, FRENK E, HOHL D, ROOP DR. (1992) Mutations in the rod domains of keratins 1 and 10 in epidermolytic hyperkeratosis. Science 257:1128-30

ROTHNAGEL JA, WOJCIK S, LIEFER KM, DOMINEY AM, HUBER M, HOHL D, ROOP DR. (1995). Mutations in the $1 A$ domain of keratin 9 in patients with epidermolytic palmoplantar keratoderma. J Invest Dermatol. 104: 430-3.

ROTHNAGEL JA, TRAUPE H, WOJCIK S, HUBER M, HOHL D, PITTELKOW MR, SAEKI H, ISHIBASHI Y, ROOP DR. (1994). Mutations in the rod domain of keratin $2 \mathrm{e}$ in patients with ichthyosis bullosa of Siemens. Nat Genet7: 485-90.

RUSSELL LJ, DIGIOVANNA JJ, ROGERS GR, STEINERT PM, HASHEM N, COMPTON JG, BALE SJ. (1995). Mutations in the gene for transglutaminase 1 in autosomal recessive lamellar ichthyosis. Nat Genet 9: 279-83.

SAKUNTABHAI A, RUIZ-PEREZ V, CARTER S, JACOBSEN N, BURGE S, MONK S, SMITH M, MUNRO CS, O'DONOVAN M, CRADDOCK N, KUCHERLAPATI R, REES JL, OWEN M, LATHROP GM, MONACO AP, STRACHAN T, HOVNANIAN A. (1999). Mutations in ATP2A2, encoding a Ca2+ pump, cause Darier disease. Nat Genet 21: 271-7.

SATO N, LEOPOLD PL, CRYSTAL RG. (1999). Induction of the hair growth phase in postnatal mice by localized transient expression of Sonic hedgehog. J Clin Invest 104: 855-64.

SCHMIDT-ULLRICH R, AEBISCHER T, HULSKEN J, BIRCHMEIER W, KLEMM U, SCHEIDEREIT C. (2001). Requirement of NF-kappaB/Rel for the development of hair follicles and other epidermal appendices. Development 128: 3843-53.

SHAMSHER MK, NAVSARIA HA, STEVENS HP, RATNAVEL RC, PURKIS PE, KELSELL DP, MCLEAN WH, COOK LJ, GRIFFITHS WA, GSCHMEISSNER S, etal. (1995). Novel mutations in keratin 16 gene underly focal non-epidermolytic palmoplantar keratoderma (NEPPK) in two families. Hum MolGenet4: 1875-81.
SINCLAIR R, CARGNELLO J, CHOW CW. (1999). Loose anagen syndrome. Exp Dermatol. 8: 297-8.

SPRECHER E, ISHIDA-YAMAMOTO A, BECKER OM, MAREKOV L, MILLER CJ, STEINERT PM, NELDNER K, RICHARD G. (2001). Evidence for novel functions of the keratin tail emerging from a mutation causing ichthyosis hystrix. $J$ Invest Dermato/116: 511-9.

SRIVASTAVA AK, PISPA J, HARTUNG AJ, DU Y, EZER S, JENKS T, SHIMADA T, PEKKANEN M, MIKKOLA ML, KO MS, THESLEFF I, KERE J, SCHLESSINGER D. (1997) The Tabby phenotype is caused by mutation in a mouse homologue of the EDA gene that reveals novel mouse and human exons and encodes a protein (ectodysplasin-A) with collagenous domains. Proc Nat/ Acad Sci USA. 94: 13069-74.

SUDBRAK R, BROWN J, DOBSON-STONE C, CARTER S, RAMSER J, WHITE J, HEALY E, DISSANAYAKE M, LARREGUE M, PERRUSSEL M, LEHRACH H, MUNRO CS, STRACHAN T, BURGE S, HOVNANIAN A, MONACO AP. (2000). Hailey-Hailey disease is caused by mutations in ATP2C1 encoding a novel $\mathrm{Ca}(2+)$ pump. Hum Mol Genet 9: 1131-40.

SUGA Y, JARNIK M, ATTAR PS, LONGLEY MA, BUNDMAN D, STEVEN AC, KOCH PJ, ROOP DR. (2000). Transgenic mice expressing a mutant form of loricrin reveal the molecular basis of the skin diseases, Vohwinkel syndrome and progressive symmetric erythrokeratoderma. J Cel/ Bio/151: 401-12.

TOOMES C, JAMES J, WOOD AJ, WU CL, MCCORMICK D, LENCH N, HEWITT C, MOYNIHAN L, ROBERTS E, WOODS CG, MARKHAM A, WONG M, WIDMER R, GHAFFAR KA, PEMBERTON M, HUSSEIN IR, TEMTAMY SA, DAVIES R, READ AP, SLOAN P, DIXON MJ, THAKKER NS. (1999). Loss-offunction mutations in the cathepsin $C$ gene result in periodontal disease and palmoplantar keratosis. Nat Genet. 23: 421-4.

VAN GENDEREN C, OKAMURA RM, FARINAS I, QUO RG, PARSLOW TG, BRUHN L, GROSSCHEDL R. (1994). Development of several organs that require inductive epithelial-mesenchymal interactions is impaired in LEF -1deficient mice. Genes Dev. 8: 2691-703.

WANG LC, LIU ZY, GAMBARDELLA L, DELACOUR A, SHAPIRO R, YANG J, SIZING I, RAYHORN P, GARBER EA, BENJAMIN CD, WILLIAMS KP, TAYLOR FR, BARRANDON Y, LING L, BURKLY LC. (2000). Regular articles: conditional disruption of hedgehog signaling pathway defines its critical role in hair and regeneration. $J$ Invest Dermatol114: 901-8.

WEEDA G, EVENO E, DONKER I, VERMEULEN W, CHEVALLIER-LAGENTE O, TAIEB A, STARY A, HOEIJMAKERS JH, MEZZINA M, SARASIN A. (1997). A mutation in the XPB/ERCC3 DNA repair transcription gene, associated with trichothiodystrophy. Am J Hum Genet 60:320-9.

WHITTOCKNV, ASHTON GH, DOPPING-HEPENSTAL PJ, GRATIAN MJ, KEANE FM, EADY RA, MCGRATH JA. (1999). Striate palmoplantar keratoderma resulting from desmoplakin haploinsufficiency. J Invest Dermatol. 113: 940-6.

WHITTOCK, N.V. and BOWER, C. (2003) Genetic evidence for a novel human desmosomal cadherin, desmoglein 4. J Invest Dermatol. 120: 523-30.

WINTER H, ROGERS MA, LANGBEIN L, STEVENS HP, LEIGH IM, LABREZE C, ROUL S, TAIEB A, KRIEG T, SCHWEIZER J. (1997). Mutations in the hair cortex keratin $\mathrm{hHb} 6$ cause the inherited hair disease monilethrix. Nat Genet 16 : 372-4.

WINTER H, ROGERS MA, GEBHARDT M, WOLLINA U, BOXALL L, CHITAYAT D, BABUL-HIRJI R, STEVENS HP, ZLOTOGORSKI A, SCHWEIZER J. (1997). A new mutation in the type II hair cortex keratin $\mathrm{hHb} 1$ involved in the inherited hair disorder monilethrix. Hum Genet 101: 165-9.

YANG A, SCHWEITZER R, SUN D, KAGHAD M, WALKER N, BRONSON RT, TABIN C, SHARPE A, CAPUT D, CRUM C, MCKEON F.(1999). p63 is essential for regenerative proliferation in limb, craniofacial and epithelial development. Nature 398:714-8.

ZLOTOGORSKI A, AHMAD W, CHRISTIANO AM. (1998). Congenital atrichia in five Arab Palestinian families resulting from a deletion mutation in the human hairless gene. Hum Genet. 103: 400-4. 